\title{
Current understanding of the structure and function of family B GPCRs to design novel drugs
}

\author{
Vlasios Karageorgos ${ }^{1} \cdot$ Maria Venihaki $^{2} \cdot$ Stelios Sakellaris $^{1} \cdot$ Michail Pardalos $^{1} \cdot$ George Kontakis $^{3}$. \\ Minos-Timotheos Matsoukas ${ }^{4} \cdot$ Achille Gravanis $^{1} \cdot$ Andreas Margioris $^{2} \cdot$ George Liapakis $^{1}$
}

Received: 3 October 2017 / Accepted: 25 January 2018 /Published online: 19 April 2018

(C) Hellenic Endocrine Society 2018

\begin{abstract}
Family B of G-protein-coupled receptors (GPCRs) and their ligands play a central role in a number of homeostatic mechanisms in the endocrine, gastrointestinal, skeletal, immune, cardiovascular and central nervous systems. Alterations in family B GPCRregulated homeostatic mechanisms may cause a variety of potentially life-threatening conditions, signifying the necessity to develop novel ligands targeting these receptors. Obtaining structural and functional information on family B GPCRs will accelerate the development of novel drugs to target these receptors. Family B GPCRs are proteins that span the plasma membrane seven times, thus forming seven transmembrane domains (TM1-TM7) which are connected to each other by three extracellular (EL) and three intracellular (IL) loops. In addition, these receptors have a long extracellular N-domain and an intracellular C-tail. The upper parts of the TMs and ELs form the J-domain of receptors. The C-terminal region of peptides first binds to the Ndomain of receptors. This 'first-step' interaction orients the $\mathrm{N}$-terminal region of peptides towards the J-domain of receptors, thus resulting in a 'second-step' of ligand-receptor interaction that activates the receptor. Activation-associated structural changes of receptors are transmitted through TMs to their intracellular regions and are responsible for their interaction with the G proteins and activation of the latter, thus resulting in a biological effect. This review summarizes the current information regarding the structure and function of family B GPCRs and their physiological and pathophysiological roles.
\end{abstract}

Keywords Family B GPCRs · Ligands · Binding · Receptor activation · Antagonists · Structure · Signaling · Physiological/ pathophysiological role

\section{Introduction}

Family B of G-protein-coupled receptors (GPCRs) consists of 15 members. It is also identified as a secretin-like family since the secretin receptor was the first to be cloned [1]. Family B GPCRs and the peptides that bind them are involved in a multitude of physiological and pathophysiological conditions.

George Liapakis

liapakig@uoc.gr

1 Department of Pharmacology, School of Medicine, University of Crete, Voutes, 71003 Heraklion, Crete, Greece

2 Department of Clinical Chemistry, School of Medicine, University of Crete, Heraklion, Crete, Greece

3 Department of Orthopedics, University Hospital of Heraklion, Crete, Greece

4 Department of Pharmacy, University of Patras, 26500 Patras, Greece
This renders family B receptors important targets for the development of peptide and non-peptide analogues.

Family B of GPCRs belongs to the superfamily of GPCRs, which also includes the families of rhodopsin, glutamate, adhesion and frizzled/taste2 and comprises the largest family of proteins in the human body [2]. GPCRs are proteins that span the plasma membrane seven times, thus forming seven transmembrane domains (TM1-TM7), which are connected to each other by three extracellular (EL) and three intracellular (IL) loops. The extracellular loops and the upper parts of the TMs form the J domain of receptors. In addition, these receptors have an extracellular $\mathrm{N}$-domain (or ECD) and an intracellular C-tail. Binding of ligands to the extracellular region of family B GPCRs is associated with conformational changes. Such structural changes are transmitted through the transmembrane domains (TMs) to their cytoplasmic regions and are responsible for receptor interaction with $G$ proteins and activation of the latter, thus resulting in biological responses. 
The members of the family of B GPCRs are the following:

1. Calcitonin (CT) receptor (CTR)

2. Calcitonin receptor-like receptor (CRLR or CLR)

3. Corticotropin-releasing hormone (CRF) receptors type 1 (CRF1R)

4. CRF receptors type 2 (CRF2R)

5. Glucagon receptor (GCGR)

6. Gastric inhibitory polypeptide (GIP) receptor (GIPR)

7. Glucagon-like peptide 1 (GLP-1) receptor (GLP1R)

8. Glucagon-like peptide 2 (GLP-2) receptor (GLP2R)

9. Growth hormone-releasing hormone $(\mathrm{GHRH})$ receptor (GHRHR)

10. Vasoactive intestinal peptide (VIP) receptors type 1 (VPAC1R)

11. VIP receptors type 2 (VPAC2R)

12. Pituitary adenylyl cyclase-activating protein (PACAP: $\mathrm{PACAP}_{27}, \mathrm{PACAP}_{38}$ ) receptor (PAC1R)

13. Parathyroid hormone (PTH) receptors type 1 (PTH1R)

14. PTH receptors type 2 (PTH2R)

15. Secretin receptor (SCTR) $[2,3]$.

Each of these receptors is present in several different isoforms thus increasing the number of family B GPCRs to more than 15 . For example, the CRF1R exists in isoforms identified as CRF-R $1 \alpha$, CRF-R $1 \beta$, CRF-R1c, CRFR1d, CRF-R1e, CRF-R1f, CRF-R1g, CRF-R1h, whereas the isoforms of CRF2R are CRF-R2 $\alpha$, CRF-R $2 \beta$ and CRF-R2 $\gamma[4]$.

CTR and CRLR can associate with the receptor activitymodifying proteins (RAMPs), RAMP1, RAMP2 and RAMP3 [5-8]. RAMPs are plasma membrane proteins that have a single transmembrane domain, an extracellular $\mathrm{N}$ terminus and an intracellular C-region [9]. Association of CRLR with distinct RAMPs provides the receptor with different pharmacological properties. Association of CRLR with RAMP1 creates the receptor that binds CGRP, whereas its association with RAMP2 or RAMP3 creates the receptor that binds adrenomedullin. As CRLR, CTR is able to associate with RAMP1, RAMP2 and RAMP3 resulting in the formation of amylin receptors, AMY1, AMY2 and AMY3, respectively [10]. The CTR alone is a highaffinity receptor for calcitonin, whereas the AMY1 receptor has high affinity for amylin and CGRP. AMY2 and AMY3 receptors are high-affinity amylin receptors with lower affinity for related peptides [10]. Although the other family B GPCRs, such as CRF1R, VPAC1R, VPAC2R, GCGR, PTH2R and PTH1R, have been shown to associate with RAMPs, there is little information on the consequences of this complexation $[11,12]$. In some cases, this interaction altered the signaling properties or cell surface expression of these receptors without however changing their binding phenotype $[11,12]$.

\section{Family B GPCRs and their ligands in homeostatic loops and their clinical significance}

Family B GPCRs and their ligands play a central role in multiple homeostatic mechanisms within the endocrine, central nervous, immune, skeletal, cardiovascular and gastrointestinal systems (Fig. 1). Alterations in family B GPCR-regulated homeostatic mechanisms are associated with a variety of potentially life-threatening pathophysiological conditions.

A variety of drugs targeting family B GPCRs have been created and are in clinical use to treat life-threatening diseases (Table 1). Modifications of GLP-1 led to the creation of marketed analogues, including liraglutide [13, 14]. Liraglutide treatment of patients with type 2 diabetes for 1 week improved their glycemic control [13]. Importantly, long-term administration of liraglutide to patients with type 2 diabetes improved glycemic control and showed extraglycemic effects, including beneficial effects on cardiovascular and renal outcomes [15-18]. Similarly, amylin analogues, such as pramlintide, are used for the treatment of diabetes mellitus. Pramlintide has been shown to improve multiple glycemic parameters and reduce body weight (Table 1) [19-21]. Furthermore, the GHRH analog, tesamorelin, has recently been approved for the reduction of excess abdominal fat in HIV-infected patients with lipodystrophy [22]. Antiretroviral therapy of HIV-infected patients could result in metabolic complications and changes in body composition. GHRH treatment of these patients is superior to GH treatment because GHRH stimulates the synthesis and pulsatile release of endogenous GH [22]. In contrast, exogenously administrated GH could lead to sustained levels of the hormone as it has several adverse effects including insulin resistance.

Teriparatide, a PTH analogue, is also therapeutically important since it is used for the treatment of osteoporosis (Table 1) [23-25]. Teriparatide not only increases bone mass but also improves microarchitecture, resulting in increased mechanical resistance and improved strength of bone. Recently, the PTH analogue abaloparatide received its first global approval, in the USA, for the treatment of postmenopausal women with osteoporosis at high risk of fracture [26, 27]. Other drugs targeting family B GPCRs which could also be used for the treatment of osteoporosis are calcitonin and its analogue elcatonin (Table 1) [28, 29].

Marketed drugs that bind to family B GPCRs also include several GLP-2 analogues. Among them, teduglutide is used for the treatment of short-bowel syndrome and other gastrointestinal disorders [30-32]. Moreover, there are many ligands for family B GPCRs that are in clinical trials, such as the human monoclonal antibody Erenumab, which inhibits the CGRPR, for the prevention of migraine [33, 34], and drugs targeting the CRF receptors. Small non-peptide CRF1R-selective antagonists are in clinical trials for the potential treatment of anxiety 
Fig. 1 Physiology of ligands for family B GPCRs. Family B GPCRs and their ligands are located in various physiological systems, playing important functional roles
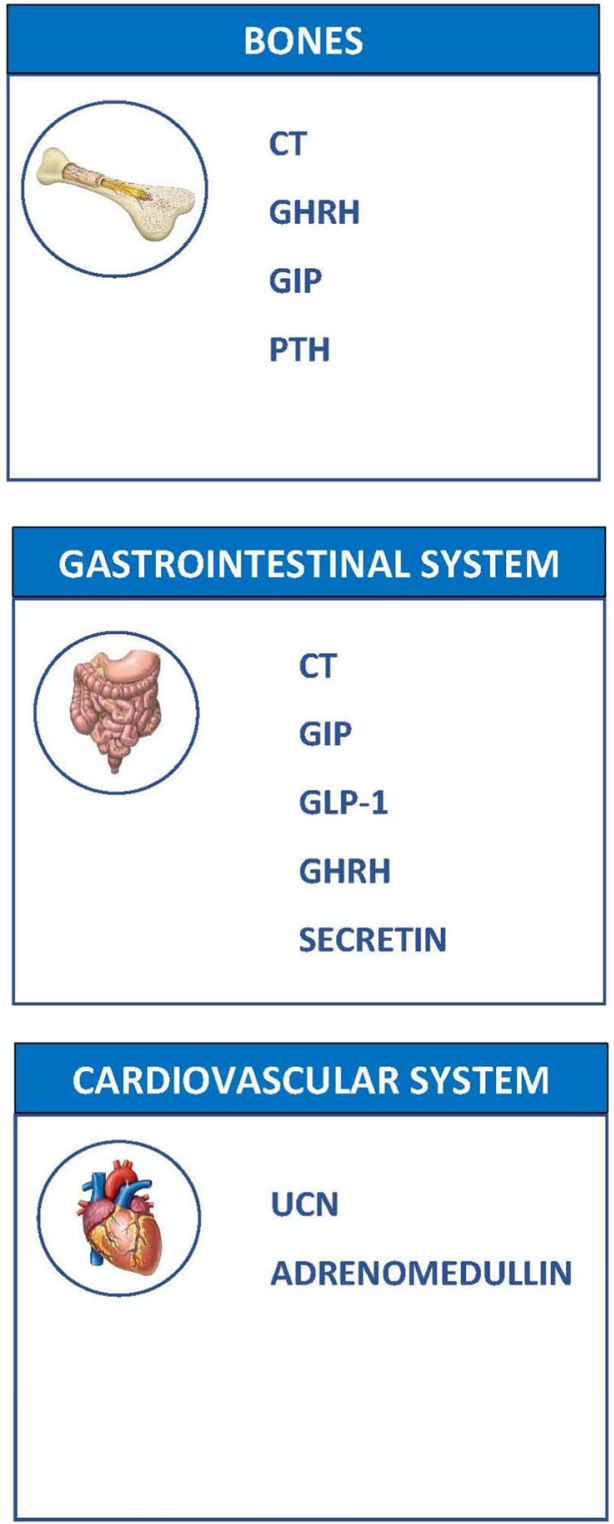

CENTRAL NERVOUS SYSTEM
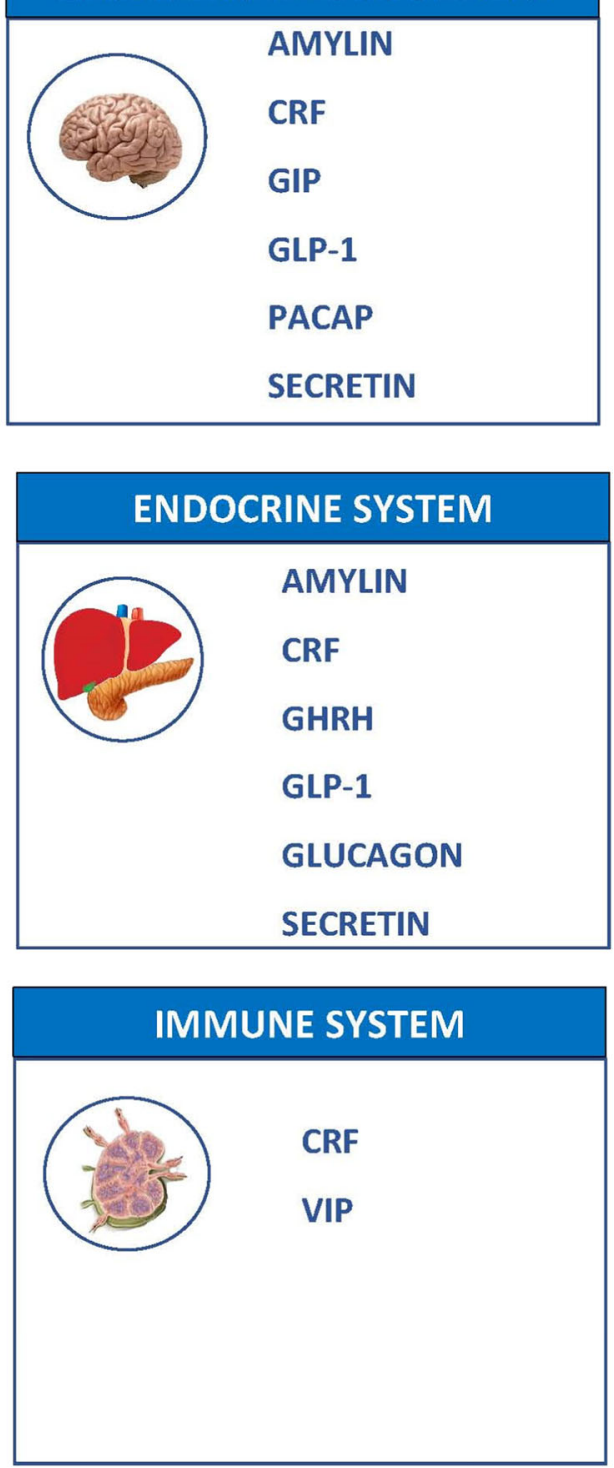

and irritable bowel syndrome [35, 36], while a synthetic preparation of CRF (corticorelin) is being considered as a potential treatment for the reduction of peritumoral cerebral oedema, as a result of the leakage of oedematous brain tumour fluid from abnormal tumour vasculature (Table 1) [37, 38].

\section{Interaction of family B GPCRs with their ligands}

\section{Structural-functional properties of peptides of family B GPCRs}

The peptides of family B GPCRs contain a central region which connects an amino-terminal (N-terminal region) with a carboxyl-terminal region (C-terminal region). Alanine mutations of several $\mathrm{N}$ - and C-terminal residues of $\mathrm{CRF}$, VIP and PACAP decreased or led to complete loss of their binding and/or biological activity [39-45]. These studies suggest the functional importance of $\mathrm{N}$ - and C-regions of peptides for family B GPCRs. Additional studies have suggested that the C-terminal region of peptides is mostly important for ligand binding, whereas their N-terminal region is essential for receptor activation. Differential truncation of the $\mathrm{C}$-terminal region of PACAP resulted in a decrease or loss of binding of peptide to its receptors [46]. As PACAP, deletion of amino acids from the C-terminal region of CRF decreased its biological activity, possibly as a result of decreased ability of the peptide to bind to its receptor [47]. Likewise, deletion of Cterminal residues from the CRF analogue, urotensin, resulted in truncated peptides that decreased biological activity of urotensin without, however, abolishing it [48]. In contrast, 
Table 1 Drugs of class B family receptors and their therapeutic role

\begin{tabular}{lll}
\hline Receptor & Drug & Disease \\
\hline PTH1R, PTH2R & Teriparatide (agonist) Abaloparatide (agonist) & Osteoporosis \\
GCGR & Glucagon (agonist) & Diabetes \\
AMY1, AMY2, AMY3 & Pramlintide (agonist) & Diabetes \\
CRF1R, CRF2R & Antalarmin (antagonist) Corticorelin (agonist) & Stress, cerebral oedema \\
CTR & Calcitonin (agonist) Elcatonin (agonist) & Osteoporosis \\
GLP1R, GLP2R & Exanatide (agonist) Liraglutide (agonist) & Diabetes \\
CGRPR & Lixisenatide (agonist) & Migraine \\
\hline
\end{tabular}

The asterisk * indicates a drug in clinical phase 3 trials. The references from studies using the drugs listed in the table are included in the text deletion of N-terminal residues from urotensin resulted in biologically inactive analogues [48]. Similarly, deletion of the first eight N-terminal residues of CRF resulted in loss of its biological activity [49]. Interestingly, this inactive truncated analogue still bound to its receptor antagonizing the biological actions of CRF [49]. Likewise, several N-terminally truncated analogues of VIP, exendin (a GLP-1-related peptide) and calcitonin analogues, did not display agonist properties [50-53]. However, they were able to bind to their receptors, displaying antagonistic properties. The ability of peptides to bind to receptor and simultaneously lose their biological activity, after truncation of their N-terminal region, was used to create potent antagonists.

In addition to their $\mathrm{C}$ - and $\mathrm{N}$-termini, an important role in the biological activity of peptides is played by their ability to adopt an $\alpha$-helical conformation [54-60]. It is possible that peptides, before reaching their receptors, could pre-form a helical structure within the plasma membrane. A two-step ligand transportation model has been proposed in a previous study in which a peptide initially binds nonspecifically to plasma membrane to form an $\alpha$-helix in its $\mathrm{C}$-terminal region, and then diffuses in search of its receptor [60]. This model is in agreement with the abilities of peptides to adopt an $\alpha$-helical conformation in hydrophobic or amphiphilic environments [55, 60-72]. In contrast, in aqueous solutions, these peptides are generally disordered.

Replacement of CRF residues by $\alpha$-helical preferring ones maximized the $\alpha$-helix-forming potential of peptide and resulted in an increase of its biological potency [49]. Moreover, connecting the $\mathrm{N}$ - and $\mathrm{C}$-terminal regions of $\mathrm{CRF}$ and the CRF-related peptide, urocortin, with a linker rich in alanines (Ala has high helix forming propensity [73]) or with highly charged linkers forming $\alpha$-helices resulted in analogues equipotent to parental peptides [74]. In contrast, connecting the $\mathrm{N}$ - and C-terminal regions of CRF peptides with highly flexible linkers created analogues with decreased biological potencies [74]. It has also been proposed that reducing the probability of calcitonin peptides to form an amphipathic helix structure decreases binding to their receptors [75]. Differences in the helicity of GLP-1 and exendin could also contribute to their different binding affinities for the N-domain of GLP1R [76].

\section{Two-domain binding model of ligand/receptor interaction}

The two-domain binding model suggests that the $\mathrm{C}$ - and $\mathrm{N}$ terminal regions of peptides interact with the $\mathrm{N}$ - and $\mathrm{J}$ domains of receptors of family B GPCRs, respectively. The interaction C-region of the peptide/ $\mathrm{N}$-domain of the receptor has been suggested in previous crystallization and NMR studies of $\mathrm{N}$-domains of different receptors in complex with their ligands [54-59, 77, 78]. This mode of interaction has also been suggested in several mutagenesis studies as well as in a biophysical study which has shown that the C-terminal region of secretin binds to a groove above a beta-hairpin region of the $\mathrm{N}$-domain of its receptor [79]. In mutagenesis studies, N-terminally truncated analogues of CRF, urocortin and exendin (with intact $\mathrm{C}$-terminal regions) have been shown to bind with high affinity either to fragments of their receptors containing the $\mathrm{N}$-terminal domain or to receptors maintaining their N-domain and lacking the J-domain, which has been replaced by the corresponding region of a different receptor [76, 80-82]. The interaction between the C-terminal region of peptides and the $\mathrm{N}$-domain of receptors has also been suggested as being important for the binding of adrenomedullin, glucagon and GLP-1 to their receptors [45, 83]. Supportive evidence for this mode of peptide/receptor interaction has been provided in a photocrosslinking study of CTR, which showed that the C-terminal amino acid 26 of calcitonin is in close proximity to $\mathrm{Thr} 30$ of the N-domain of the receptor [84].

The interaction N-region of the peptide/J-domain of the receptor has been suggested in a mutagenesis study of CRF1R [85]. Specifically, Trp259 and Phe260 in the second extracellular loop (EL2) of the J-domain of CRF1R have been shown to interact with $\mathrm{N}$-terminal residues $8-10$ of sauvagine and the corresponding region of CRF. In accordance with these findings, a previous photocrosslinking study has 
demonstrated that Lys 257 of the EL2 of CRF1R lies near the $\mathrm{N}$-terminal region of CRF peptides [86]. In addition to EL2, EL1, TM1, TM5, TM6 and TM7 of the J-domain of CRF1R have been shown to be in close proximity to the N-terminal region of CRF peptides [87-89]. Similarly, the amino acids in the N-terminal region of PTH, secretin, calcitonin, glucagon and GLP-1, have been demonstrated to be in close proximity to the J-domain of their receptors in previous studies using a variety of different methodologies [83, 90-96]. The interaction between the N-terminal region of peptides and the Jdomain of receptors is crucial for receptor activation. This observation is supported by the aforementioned functional importance of the N-region of peptides and by the results of a mutagenesis study which used chimeras consisting of the Jdomain of the calcitonin receptor (J-CTR) and the N-domain of the PTH receptor (N-PTHR) and vice versa, as well as hybrid peptides consisting of the C-region of PTH (PTH-C) and the N-region of calcitonin (CT-N) and vice versa [97]. A chimeric receptor (for example, N-PTHR + J-CTR) was activated only by the hybrid peptide, which is composed of a Nterminal region (for example, CT-N) that corresponds to the Jdomain of the receptor (J-CTR) and a C-terminal region (for example, PTH-C) that matches the $\mathrm{N}$-domain of the receptor (N-PTHR).

\section{Two-step binding model of ligand/receptor interaction}

The interaction of peptides, such as PTH or CRF, with their family B GPCRs has been proposed as involving two steps (Fig. 2) [98-100]. In the first step, the C-terminal region of peptides interacts with the $\mathrm{N}$-domain of receptors. It has been suggested that this "first-step" interaction orients the Nterminal region of peptides towards the J-domain of the receptor, resulting in their interaction with each other. This "secondstep" interaction is responsible for receptor activation. Peptides lacking the $\mathrm{N}$-terminal region are antagonists because they bind to the N-domain of the receptor in the "firststep" interaction, thus blocking agonist binding, but cannot proceed to the "second-step" as they cannot bind to the Jdomain and activate the receptor. The two-step model of ligand/receptor interaction is further supported by a study that replaced the $\mathrm{N}$-domain of CRF1R by the first $16 \mathrm{~N}$-terminal residues (signaling region of CRF [101]). This created the chimeric receptor, CRF $[1-16] / \mathrm{R} 1 \Delta \mathrm{N}$, in which the $\mathrm{N}$ terminal region of CRF was tethered to the J-domain of the receptor. Such tethering mimicked the "first-step" of receptorpeptide interaction that placed the signaling region of CRF close to the J-domain of CRF1R to interact with each other

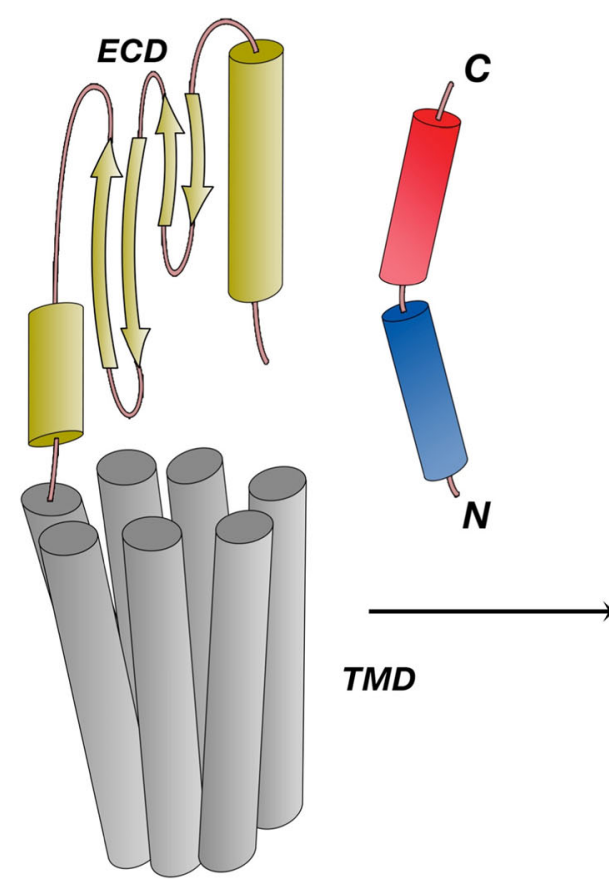

Fig. 2 Schematic representation of the two-step model. Family B GPCRs consist of an extracellular $\mathrm{N}$-terminal region $(\mathrm{N}$-domain or ECD, in yellow) and a J-domain. The $\beta$-strands of the $\beta$-sheets of the $\mathrm{N}$-domain are depicted as arrows. The J-domain consists of the transmembrane domains (TMs or TMD, in gray) and the extracellular loops (ELs) connecting the TMD. For the purpose of clarity, the ELs are not included in the figure. Peptide agonists for family B GPCRs consist of
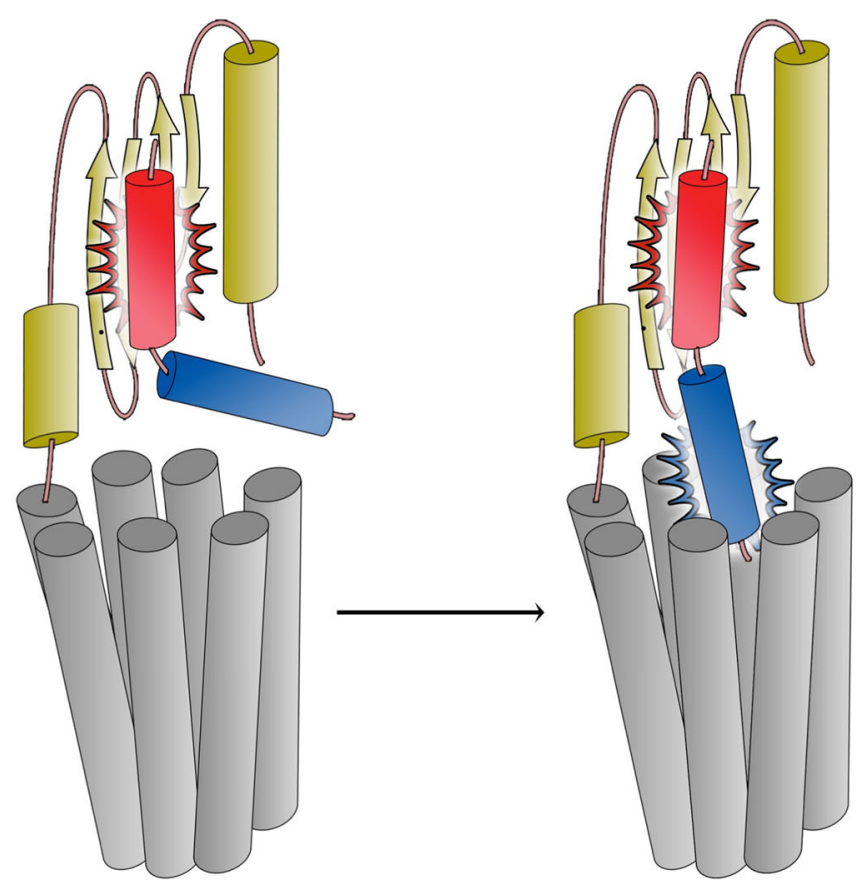

a N-terminal region $(\mathrm{N})$ and a $\mathrm{C}$-terminal region $(\mathrm{C})$. According to the two-step model, the C-terminal region of peptides (red) interacts with the $\mathrm{N}$-domain of receptors. This "first-step" interaction orients the N-terminal region of peptides (blue) towards the J-domain of the receptor, resulting in their interaction with each other. This "second-step" interaction is responsible for receptor activation 
and activate the receptor. Indeed, the CRF $[1-16] / R 1 \Delta N$ chimera was active in the absence of an exogenously administrated agonist (constitutively active receptor). Antalarmin binds to the TMs of the CRF [1-16]/R1 $\Delta \mathrm{N}$ chimera and blocks receptor activation [102]. In contrast, the constitutive activity of the CRF $[1-16] / R 1 \Delta \mathrm{N}$ chimera was not blocked by astressin, which interacts with the $\mathrm{N}$-domain of wild-type CRF1R [101].

The two-step model of ligand binding and receptor activation is supported by a FRET study which tagged the PTH with tetramethyl-rhodamine and its receptor with green fluorescent protein (GFP) [103]. The results of this study suggested that PTH initially interacts with the N-domain of its receptor ("first-step" interaction) with a fast time constant $(\tau=\sim$ $140 \mathrm{~ms}$ ) and then ("second-step" interaction) with the Jdomain of the receptor more slowly $(\tau=\sim 1 \mathrm{~s})$. These data also suggested that the slow "second-step" interaction coincides with an activation-associated conformational change of receptor.

\section{Structural and functional characteristics of the N-domain and TMs of family B GPCRs}

\section{The $\mathrm{N}$-domain}

Based on the data of NMR and crystallography studies, the Ndomain of family B GPCRs has a conserved structural motif ( $\alpha-\beta-\beta-\alpha$ motif), which consists of the following: (1) a Nterminal $\alpha$-helix, (2) two anti-parallel $\beta$-sheets, termed $\beta 1-\beta 2$ and $\beta 3-\beta 4$, each consisting of two $\beta$-strands (Figs. 3 and 4) and (3) an $\alpha$-helical $C$-terminal region [54-59, 77, 78, 104-109]. $\beta$-sheet topology is known as the short consensus repeat (SCR) or Sushi domain. Sushi domains play an important role in protein-protein interactions, such as those of the complement system $[77,105,110,111]$. Loop 2 ( $\beta 1-\beta 2$ loop) connects the $\beta 1$ and $\beta 2$ strands of the $\beta 1-\beta 2$ sheet, whereas loop 4 links the $\beta 3$ and $\beta 4$ strands of the $\beta 3-\beta 4$ sheet. The $N$ terminal $\alpha$-helix and $\beta 1-\beta 2$ sheet are connected with each other by loop 1 . Three highly conserved disulfide bonds (S$\mathrm{S}$ bonds) link these sheets with each other and with other regions of the $\mathrm{N}$-domain, thus stabilizing the $\beta$-sheets $[54-59,77,78,104-106,109]$. The first S-S bond links the $\beta 1-\beta 2$ sheet and the $N$-terminal $\alpha$-helix, the second connects the two $\beta$-sheets with each other and the third links the $\beta 3-\beta 4$ sheet with the C-terminal domain [58]. Stabilization of Ndomain structure by the three disulfide bonds is crucial for receptor function, since disruption of these bonds in GLP1R, VIPR and CRF1R using $\beta$-mercaptoethanol, DTT or mutating the Cys had dramatic effects on ligand binding and biological potency [112-114].

In addition to the three conserved disulfide bonds, the structure of the N-domain of family B GPCRs is stabilized

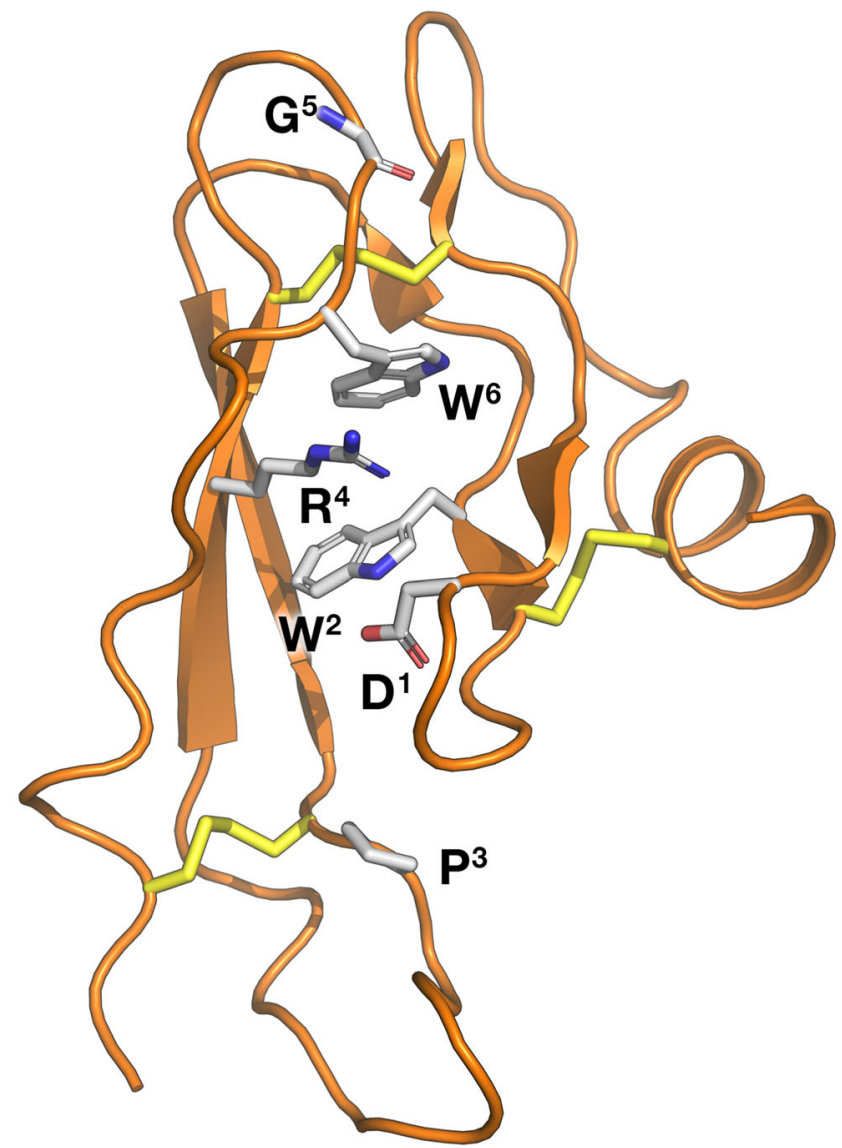

Fig. 3 Stabilizing interactions between conserved residues among family B GPCR N-domains (CRF1R N-domain in this figure). The six conserved residues are shown as white sticks. The three disulfide bonds formed by the six conserved cysteines are shown in yellow

by hydrophobic, electrostatic and hydrogen-bond interactions mostly between six conserved residues of this domain (Fig. 3) [54-59, 77, 78, 104-109]. These six conserved residues were Asp (termed Asp1; Asp49 and Asp65 of CRF1R and CRFR2 $\beta$, respectively), Trp (termed Trp2; Trp55 and Trp71 of CRF1R and CRFR-2 $\beta$, respectively), Pro (termed Pro3; Pro69 and Pro85 of CRF1R and CRFR-2 $\beta$, respectively), Arg (termed Arg4; Arg85 and Arg101 of CRF1R and CRFR-2 $\beta$, respectively), Gly (termed Gly5; Gly91 and Gly107 of CRF1R and CRFR-2 $\beta$, respectively) and Trp (termed Trp6; Trp93 and Trp109 of CRF1R and CRFR-2 $\beta$, respectively). All these residues, except Arg, are identical in family B GPCRs; Arg is Lys in CRLR, CTR, GCGR and VPAC2R. Although Arg is not identical in all members of family B GPCRs, a positively charged residue (either Arg or Lys) at this position is completely conserved among all receptors, suggesting its important functional role.

The interactions between the conserved residues of the Ndomain are crucial for the stabilization of its functional structure. It has been proposed that the interaction between Asp1 and Trp2 stabilizes the loop 2, thus contributing to the formation of the correct geometry of ligand contact sites [77, 108]. 
Fig. 4 Hormone binding to the respective $\mathrm{N}$-domains of their receptor. $\mathrm{N}$-domains and peptides are shown in cartoon representation. The $\beta$-strands of the $\beta$-sheets of the $\mathrm{N}$-domains are depicted as purple arrows, whereas the $\mathrm{N}$-terminal $\alpha$-helix is cyan colored. In specific, a Ucn 1 bound to CRF2R in orange, $\mathbf{b}$ PACAP bound to PACAPR in gray, c parathyroid hormonerelated protein $(\mathrm{PTHrP})$ bound to $\mathrm{PTH}_{1} \mathrm{R}$ in green, $\mathbf{d}$ GLP-1 bound to GLP1R in yellow, e GIP bound to GIPR in red and $\mathbf{f}$ CRF bound to CRF1R in blue. PACAP interacts with receptor on one face of the N-domain, whereas other peptides bind on the opposite face
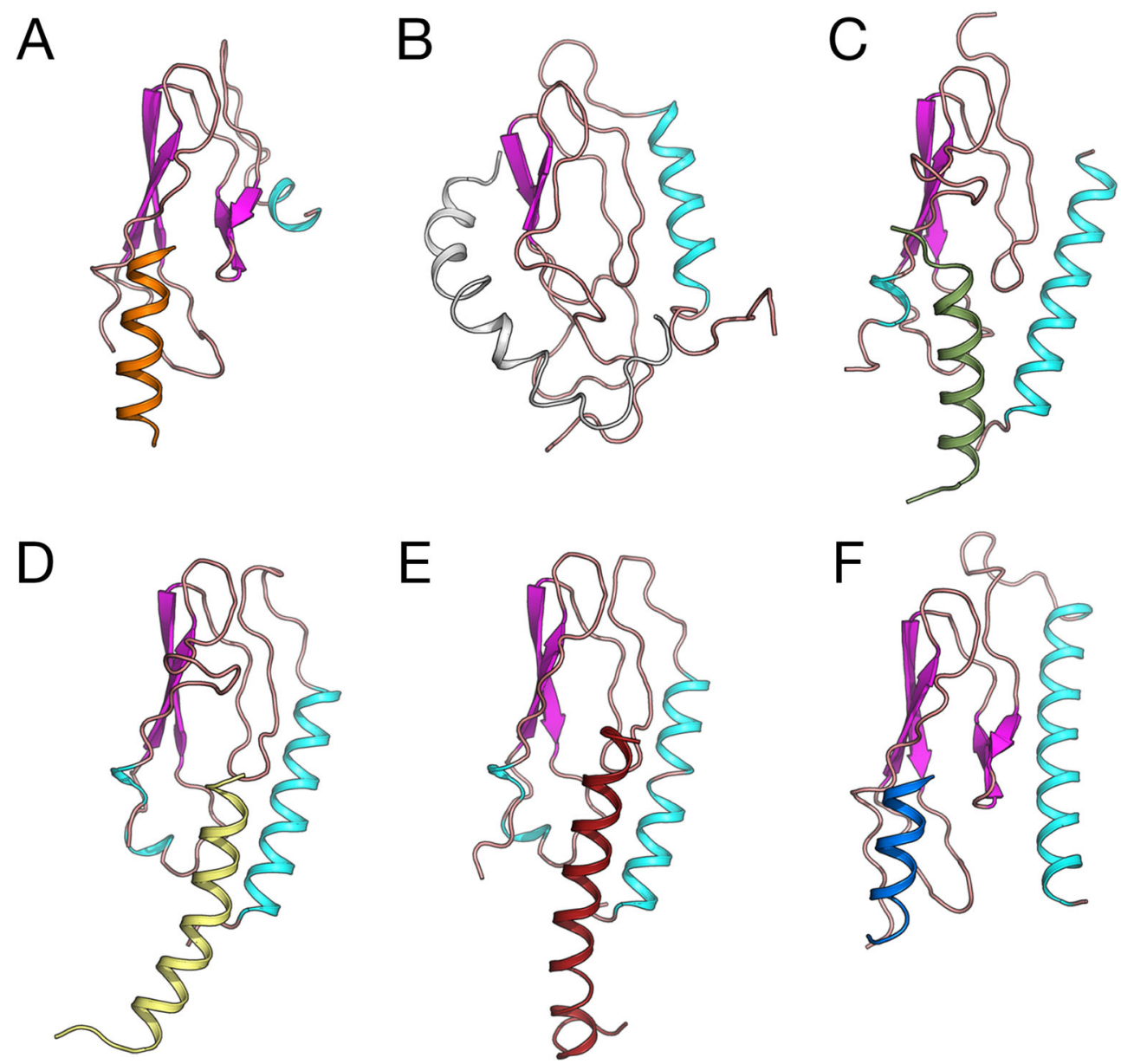

$E$
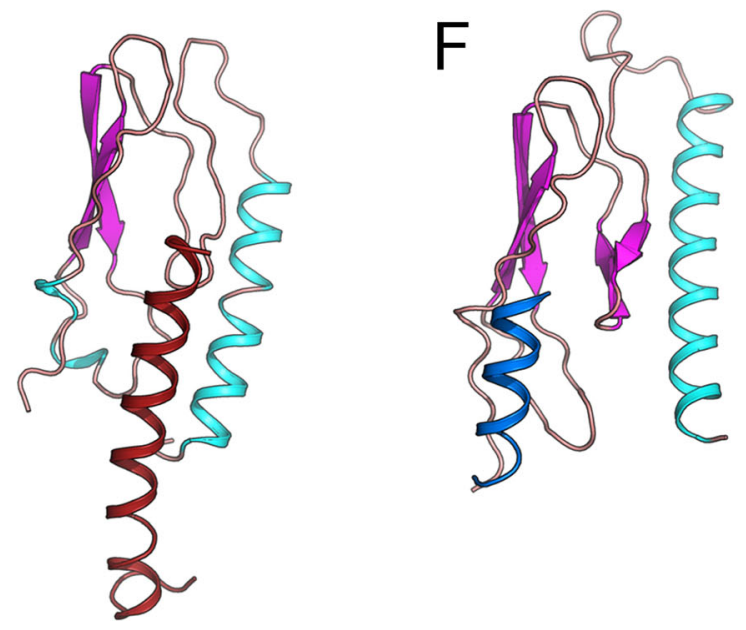

In addition, mutations of Asp1 and Arg4 most likely disrupt the structure of the $\mathrm{N}$-domain of the PAC1 receptor, resulting in a misfolded or less stable structure with altered ligandbinding properties [57]. Similarly, mutation of these residues to Ala disrupted a salt bridge between them and resulted in the collapse of a well-defined three-dimensional structure of the $\mathrm{N}$-domain of the CRF receptor into a molten globule-like conformation [108]. Interestingly, mutation of Asp1 in the GHRH receptor impaired its function, resulting in a genetically transmitted dwarfism in mice [115]. This genetic abnormality is referred to as little (lit/lit) and is characterized by hypoplasia of the anterior pituitary and decrease of growth hormone mRNA and protein [115].

Peptide binding to the N-domain of family B GPCRs is associated with adoption of an $\alpha$-helical conformation of peptides [54-59, 77]. This $\alpha$-helical conformation allows hydrophobic interactions of peptides with the receptor via one face of their $\alpha$-helix and hydrophilic interactions via the other face $[54,55]$. Despite this conserved mode of binding, various ligands of family B GPCRs bind differentially to their receptors. PACAP interacts with PAC1R on one face of the Ndomain, whereas other peptides, such as PTH, GIP, GLP-1, CRF and astressin, bind on the opposite face (Fig. 4) [54,
56-59, 77, 105, 109]. Moreover, different peptides, such as PTH, GIP, GLP-1, CRF and astressin, which interact with the same face of the $\mathrm{N}$-domain of their receptors, are positioned slightly differently. For example, PTH and GIP are shifted approximately 5-8 $\AA$ as compared with CRF [77]. This might be partly due to the presence of Gly52 in loop 2 of the Ndomain of CRF1R, which is not present in the other family B GPCRs [77]. Gly52 causes loop 2 to adopt a conformation that is not stereochemically compatible with PTH or GIP located at the same position as CRF.

The role of the N-domain in ligand selectivity has also been proposed by Pal et al. who compared the electrostatic surface potentials of the crystal structures of the N-domain of CRF1R and CRF2R [78]. This study suggested that the positively charged Arg35 of the non-selective CRF is electrostatically compatible with Glu104 of CRF1R as well as with the hydrophobic surface created by Pro100 of CRF2R, which corresponds to Glu104 of CRF1R [78]. In contrast, the hydrophobic Ala35 (that corresponds to Arg35 of CRF) of the CRF2Rselective CRF analogues, urocortins II and III, is compatible with Pro100 of CRF2R but not with Glu104 of CRF1R.

An additional determinant of ligand selectivity is the association of family B GPCRs with RAMPs, which are proteins 
spanning once the plasma membrane and having an extracellular N-terminus and a cytoplasmic $\mathrm{C}$-terminus [116]. RAMPs play an important role in ligand selectivity, receptor trafficking and differential coupling of CPCRs with various $\mathrm{G}$ proteins $[117,118]$. Molecular determinants that account for distinct pharmacological profiles of a receptor complexed with different RAMPs are discussed in detail in the reviews of Archbold et al. and Hay et al. [117, 119]

\section{The transmembrane domains}

The structural changes that take place in the N-domain and the extracellular loops of family B GPCRs upon ligand binding are transmitted through the transmembrane domains (TMs) to their intracellular loops and C-tail and are responsible for receptor interaction with $\mathrm{G}$ proteins and activation of the latter [120].

Beginning in 2013, the structure of the helical TMs of two family B GPCRs was solved in three crystallographic studies on the inactive GCGR [121], the GCGR in complex with the extrahelical allosteric antagonist MK-0893 [122] and the CRF1R bound to the allosteric antagonist CP-376395 [123]. More recently, the crystal and cryo-EM structures of the GLP1R and the full-length GCGR, bound to negative allosteric modulators, as well as CTR and GLP1R in their active states bound to peptide agonists and the heterotrimeric $\mathrm{G}_{\mathrm{s}}$ protein have been reported (Fig. 5a, b) [124-127]. The structure of GLP-1R bound to the GLP1 peptide agonists and the $\mathrm{G}_{\mathrm{s}}$ protein using cryo-EM visualization revealed specific features on the mechanism of transmembrane reorientation during activation of family B GPCRs (Fig. 5a). The other structure of a family B GPCR in complex with a G protein was CTR, however without the presence of the ECD (Fig. 5b). This structure also revealed the binding mode of the peptide agonist as well as intracellular motions that govern GPCR activation. These receptors share the same seven transmembrane architectures as GPCRs of other families despite the fact that the most conserved residues of each TM are different, except TM4 in which $\operatorname{Trp}^{4.50}$ is conserved among families $\mathrm{A}, \mathrm{B}$ and $\mathrm{F}$ [128]. $\operatorname{Trp}^{4.50}$ is numbered according to the Ballesteros-Weinstein numbering scheme which has been used to number conserved TM residues in family A GPCRs [129]. Based on the Ballesteros-Weinstein numbering scheme, the fully conserved TM residues in family A receptors are named X.50 (where $\mathrm{X}$ is the number of the TM and 50 is the most conserved residue), whereas the neighbouring residues immediately before and after X.50 are named X.49 and X.51, respectively. For family B GPCRs, the conserved residues were numbered according to the Wootten numbering
A

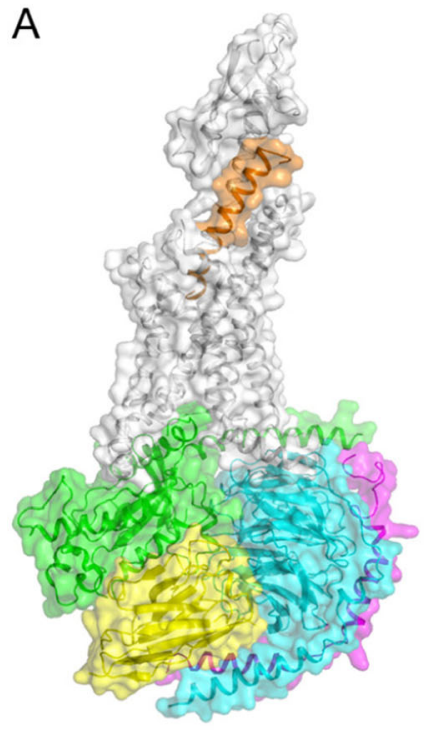

B

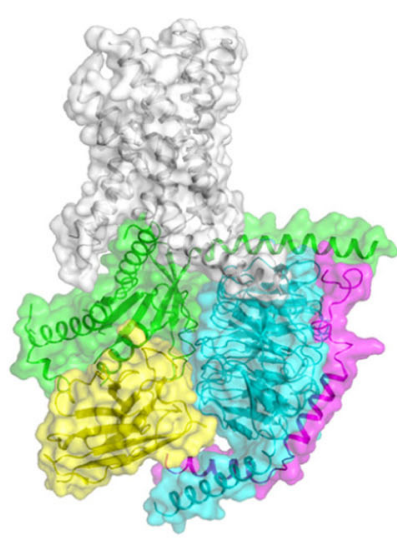

C
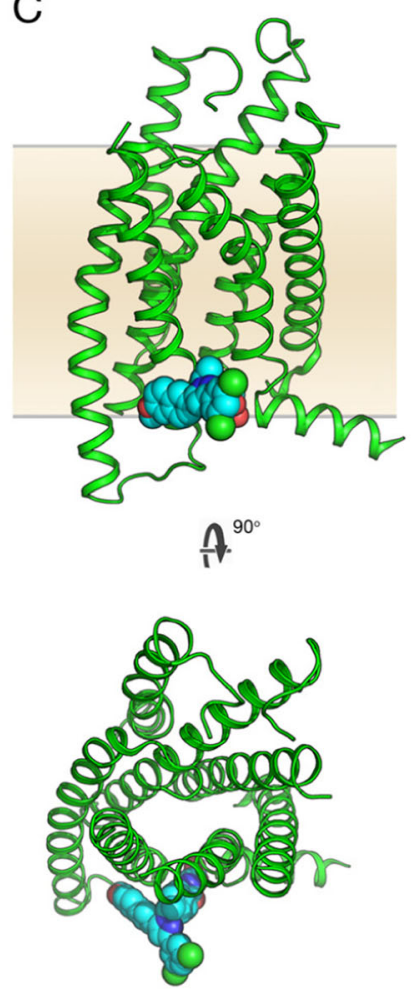

D
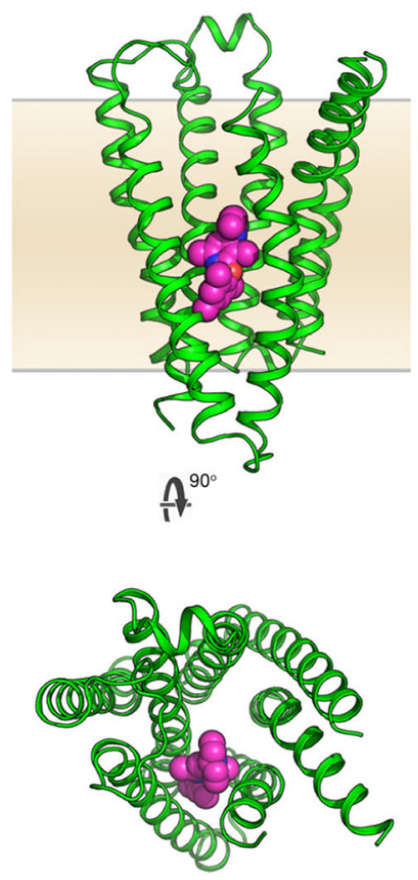

Fig. 5 Structures of a active GLP-1R (white) in complex with agonist (orange) the heterotrimeric $G_{s}$ protein $\left(G_{\alpha s}\right.$ green, $G_{\beta}$ cyan and $G_{\gamma}$ magenta) and the nanobody-35 (Nb35 yellow) that stabilizes the receptor/ $\mathrm{G}_{\mathrm{s}}$ protein complex b active CTR (white) in complex with Gs protein $\left(G_{\alpha s}\right.$ green, $G_{\beta}$ cyan and $G_{\gamma}$ magenta; Nb35, yellow).

Comparison of binding positions of $\mathbf{c}$ MK-0893 (cyan) bound to the inactive GCGR and d CP-376395 (magenta) bound to the inactive CRF1R. Non-peptide ligands in $\mathbf{c}, \mathbf{d}$ are represented as spheres in their respective colors. c, $\mathbf{d}$ Receptor-ligand complexes from different views 
scheme [130]. Although the receptors of families A and B are different, their overall fold is similar allowing the alignment of the sequences of receptors in both families based on their structures $[102,121]$. This alignment enabled us to use the Ballesteros-Weinstein general scheme to number TM residues of receptors of both families in this manuscript. This makes feasible the comparison of receptor structures belonging to family A and B GPCRs.

Comparison of the structures of family A and B GPCRs reveals that there are structural similarities and differences between their TMs. A common characteristic is the highly conserved GWGxP motif in TM4 that forms a network of structurally important interactions with TM2 and TM3 [123]. In addition, it has been proposed that a TM1-TM7 interaction between $\operatorname{Ser}^{1.46}, \operatorname{Ser}^{7.43}$ and Phe $357^{7.47}$ stabilizes a kink in TM7 [123]. This TM7 kink is different than the corresponding one in family A GPCRs and is responsible for the larger binding pocket (formed by the extracellular portions of TMs) of family B GPCRs compared to that of family A receptors. This large $\mathrm{V}$-shaped ligand-binding pocket of family $B$ receptors enables the helical hormones to reach this cavity and bind to it to promote activation.

Activation-associated conformational changes of family B GPCRs are much less elucidated than family A receptors. However, the few recently identified structures of family B GPCRs show a similar activation mechanism, where the important element is the outward movement of the TM6 intracellular part [124-127]. The crystal structure of family A, $\beta_{2}$ adrenergic receptor in complex with the $\mathrm{G}_{\mathrm{s}}$ protein, has revealed a $14 \AA$ outward movement of the intracellular part of TM6 of receptor [131]. During the activation of family B GPCRs, structural changes in the intracellular parts of TMs as well as the intracellular regions (IL1-IL3) are responsible for receptor interaction with, and activation of, multiple $G$ proteins, such as $\mathrm{G}_{\mathrm{s}}, \mathrm{G}_{\mathrm{q} / 11}$ and $\mathrm{G}_{\mathrm{i} / \mathrm{o}}$ [132-134].

Among the intracellular regions of family B GPCRs, IL3 and the intracellular parts of TM5 and TM6 have been shown to mostly participate in receptor/G protein interaction, similarly to family A GPCRs. Simultaneous disruption of the cationic amino acids of IL3 near TM5 and TM6 by tandem Ala mutations abolished the ability of CRF1R to activate G proteins [135]. Importantly, different amino acids in these regions confer the selectivity of IL3 interaction with different G proteins. Arg292, Arg310 and Lys311 have been shown to be important in the interaction of IL 3 with both $\mathrm{G}_{\mathrm{s}}$ and $\mathrm{G}_{\mathrm{i}}$ proteins, whereas Leu294, Met295 and Lys314 exhibited $\mathrm{G}_{\mathrm{s}}$ protein interaction selectivity. The participation of hydrophobic residues of IL3 in receptor/G protein interaction, in addition to ionic residues, has also been shown in different other receptors. It has been suggested that Ile290 at the proximal end of IL3 of CGRP1R interacts with $\mathrm{G}_{\mathrm{s}}$ as well as with TM6 to stabilize the conformation of IL3 [136]. Moreover, Ala mutation of Val378 and Leu379 in IL3 of PTHR reduced receptor signaling [137]. As in CRF1R, different amino acids in the IL3 of the PTHR play a differential role in receptor interaction with different $G$ proteins and activation of different signaling pathways [137]. Ala mutation of Val378 and Leu379 in IL3 of PTHR reduced inositol phosphate (IP) production, without affecting cAMP responses to $\mathrm{PTH}$. In contrast, Ala mutation of the neighbouring Thr381 decreased cAMP accumulation without altering IP responses to PTH. Similarly, different domains in the IL3 of the GLP1R are responsible for $\mathrm{G}_{\mathrm{s}}$ and $\mathrm{G}_{\mathrm{i}}$ activation [138]. The N-terminal part of IL3 of GLP1R selectively stimulates $G_{s}$, whereas the $C$-terminal part stimulates $G_{i}$ proteins. In addition to GLP1R, the crucial role of IL3 in family B GPCRs/G protein interaction has also been demonstrated in many studies on different receptors, such as VPAC1R, GCGR and secretin receptor [136, 139-145].

Using peptides derived from IL1, IL2 and IL3 of GLP1R, Bavec et al. have shown that in addition to IL3, which stimulated all $G$ proteins $\left(G_{s}, G_{o}, G_{i}\right.$ and $\left.G_{11}\right)$, IL1 and IL2 participated in receptor/G protein interaction by modulating the interactions between IL3 and different G proteins [143]. IL1 and IL2 of many family B GPCRs have also been shown to interact with $G$ proteins $[136,140,144,146]$.

The ability of family B GPCRs to interact with different G proteins and the differential contribution of different amino acids of receptor intracellular regions in these interactions are likely related to their property to adopt various conformations. Interestingly, different conformations of a receptor could also be responsible for its differential signaling through the same G protein. PTH and PTHrP have been suggested as preferentially stabilizing distinct active conformations of PTHR that can be distinguished kinetically at several steps of binding and activation [147]. PTH induces a 'locked on' active PTHR conformation, which is correlated with the formation of Rab5-positive endosomal compartments containing ligand, receptor, $\mathrm{G}_{\mathrm{s}}$ and adenylyl cyclase. Thus, PTH mediates persistent $G_{s}$ protein activation by moving to internalized compartments where it remains associated with PTHR and $\mathrm{G}_{\mathrm{s}}$. In marked contrast, PTHrP action is restricted to the cell surface where it dissociates rapidly from PTHR, prompting rapid signal termination. The ability of PTH to induce a more stable active complex with PTHR than PTHrP is physiologically important as it could be related to the higher propensity of PTH to activate bone-resorption (less bone-anabolic) than PTHrP [147]. Thus, the different duration of PTHR signaling after its activation by different ligands could determine the net physiological effect on the opposing processes of bone formation and bone resorption.

It is suggested that the association of family B GPCRs with RAMPs may alter their interaction with different $G$ proteins $[117,118]$. To determine the effects of the association of CLR with different RAMPs on receptor signaling through $G_{i}$ and $G_{s}$ proteins, Weston et al. measured $\mathrm{G}_{\mathrm{s}}$-mediated cAMP production in HEK 293 cells before and after pertussis toxin (PTX) 
treatment [118]. PTX uncouples receptors from $\mathrm{G}_{\mathrm{i}}$ proteins and therefore removes any inhibition of cAMP production. PTX pretreatment of cells co-expressing RAMP1 and CLR resulted in little increase in CGRP-mediated cAMP production. In contrast, PTX pretreatment largely increased adrenomedullin or adrenomedullin2-mediated cAMP production, suggesting strong $G_{i}$ signaling for both of these ligands that had been removed by PTX treatment. Association of CLR with RAMP2 or RAMP3 created a different signaling phenotype of CLR since PTX increased CGRP and adrenomedullin2mediated cAMP production but not that of adrenomedullin. Interestingly, the effects of RAMPs on CLR signaling were different in various cells displaying different levels of expression of $\mathrm{G}$ proteins [118].

\section{Structural determinants of allosteric binding of non-peptide molecules and antagonism}

Small non-peptide antagonists have been shown to intercalate between TMs and interact with them to allosterically block peptide binding and receptor activation-associated conformational changes $[102,123]$. The crystal structures of GCGR ${ }^{122}$ and CRF1R [123] in complex with an allosteric antagonist highlighted unexpected binding positions in both receptors, compared to GPCRs belonging to different families. GPCR structures from families $\mathrm{A}, \mathrm{C}$ and $\mathrm{F}$ have shown ligands to cluster in pockets close to the extracellular part of receptors [128]. In comparison to family A GPCRs, family B receptor structures suggest that non-peptide ligands might bind deeper towards the intracellular portions of TMs (Fig. 5c, d). The GCGR-MK-0893 structure revealed that the ligand binds towards the intracellular part and outside the 7TM and interacts with residues of TM5, TM6 and TM7 (Fig. 5c) [122]. Likewise, negative allosteric modulators PF-06372222 and NNC0640 bind in the same region of GLP1R [124]. This "clamp-like" binding mode is thought to restrict TM6 in its position, prohibiting the outward movement needed for activation $[131,148]$. In detail, the MK-0893 makes hydrophobic interactions with Leu329 $9^{5.65}$, Phe345 $5^{6.41}$, Leu352 $2^{6.48}$, Thr353 $3^{6.49}$ and Lys349 6.45 on the TM5-TM6 interface and polar interactions with Lys349 ${ }^{6.45}$, Ser350 $0^{6.46}$, Arg346 6.42 and Asn404 ${ }^{7.57}$. Similarly, allosteric antagonists PF06372222 and NNC0640 co-crystallized with GLP1R, bind to the same location. These structures could be used as guides for the design of such "extrahelical" antagonists that directly block the helical movements associated with GPCR activation.

The CRF1R crystal structure has shown a non-expected binding site of the allosteric antagonist, CP-376395, located only $\sim 4 \AA$ from the intracellular boundary of receptor between TMs 3, 5 and 6 (Fig. 5d). ${ }^{123}$ In this hydrophobic pocket, CP-376395 interacts hydrophobically with Phe284 ${ }^{5.55}$, Leu $287^{5.58}$, Ile $290^{5.61}$, Thr3 $16^{6.37}$, Leu3 $19^{6.40}$ and
Leu $320^{6.41}$ and makes one electrostatic interaction with Asn $283^{5.54}$. Phe $203^{3.40}$ has also been found to interact with the alkyl-amino group of ligands, which along with Tyr327 $27^{6.48}$ form a lid-like structure that restricts it within the binding pocket. As CP-376395, Phe203 has been found to contact another CRF1R-selective ligand, antalarmin [102]. Although amino acids that form the allosteric binding pocket are conserved between the two CRF receptors, they, however, cannot be considered as a common binding site for small molecules in these receptors. CP-376395 is highly selective towards CRF1R, having an affinity for CRF1R 10,000-fold higher than that for CRF2R [149]. This is the case of most of the CRF1R allosteric non-peptide antagonists, which share the same main pharmacophoric characteristics [35]. The selectivity of these compounds could be attributed to a possible important indirect role of residues His $199^{3.36}$ and Met $276^{5.47}$ of CRF1R in non-peptide ligand binding $[123,150]$. These residues do not interact with CP-376395 as demonstrated in the crystal structure of CRF1R [123]. However, mutation of these residues in CRF1 $\mathrm{R}$ to their corresponding CRF2R amino acids Val199 $9^{3.36}$ and Ile $276^{5.47}$ reduced the binding affinity of the structurally related CRF1R-selective allosteric antagonist NBI27914 40- and 200-fold, respectively [98, 151]. The indirect role of His $199^{3.36}$ and Met276 $6^{5.47}$ in non-peptide ligand binding could be explained based on the fact that His $199^{3.36}$ forms a hydrogen bond with Tyr327 $7^{6.48}$, whereas Met276 ${ }^{5.47}$ packs against Phe203 ${ }^{3.40}$ [123]. This structural arrangement may stabilize a lid-like structure, which affects the binding of non-peptide ligands by prohibiting them from diffusing out of the binding pocket. The absence of His $199^{3.36}$ and Met276 $6^{5.47}$ in CRF2R does not favour the formation of this lid-like structure by Phe $203^{3.40}$ and Tyr $327^{6.48}$; thus, this observation supports the important role of these residues in non-peptide ligand CRF1R selectivity. The latter assumption is supported by a recent study which, using molecular dynamics simulations, pointed to the importance of Tyr32 $27^{6.53 b}$, linking it to His $199^{3.40 \mathrm{~b}}$ [152].

The accumulating structural information on allosteric binding of family B GPCRs could identify druggable regions, such as the outside of the transmembrane domains of GCGRs. This would enable the development of non-conventional computational methods towards virtual screening and drug design on sites that interact with the membrane environment.

\section{Conclusions}

Maintenance of homeostasis is a basic prerequisite for life, ensuring the stability of the human body in response to external and internal stimuli (stressful stimuli). The maintenance of homeostasis requires numerous adaptive responses, involving, inter alia, alterations in the function of the endocrine system. A central role in the maintenance of homeostasis is 
played by family B GPCRs and their ligands by regulating the activity of the endocrine system as well as that of the gastrointestinal, skeletal, immune, cardiovascular and central nervous systems. Given that alterations in family B GPCRregulated homeostatic mechanisms affect human physiologic functions and are associated with a variety of pathophysiological conditions, the development of novel ligands targeting this family of receptors will enhance our efforts to combat various potential life-threatening diseases. While already several drugs targeting family B GPCRs are now clinically being used to treat diabetes mellitus, osteoporosis and other serious diseases, many other ligands are currently in clinical trials. Obtaining information about the structure of family B GPCRs, such as the recent cryo-EM structures, which is reviewed in this manuscript, are providing mechanistic insights not only into their activation but also regarding their targeting by small molecules. This information will further advance the development of novel drugs targeting family B GPCRs which will enrich the therapeutic armory for the treatment of a wide range of serious disorders.

Funding Part of this work was supported by an ELKE-2015 grant to G.L.

\section{Compliance with ethical standards}

Conflict of interest The authors declare that they have no conflicts of interest.

\section{References}

1. Ishihara T, Nakamura S, Kaziro Y, Takahashi T, Takahashi K, Nagata S (1991) Molecular cloning and expression of a cDNA encoding the secretin receptor. EMBO J 10:1635-1641

2. Fredriksson R, Lagerstrom MC, Lundin LG, Schioth HB (2003) The G-protein-coupled receptors in the human genome form five main families. Phylogenetic analysis, paralogon groups, and fingerprints. Mol Pharmacol 63:1256-1272

3. Alexander SP, Davenport AP, Kelly E et al (2015) The concise guide to PHARMACOLOGY 2015/16: G protein-coupled receptors. Br J Pharmacol 172:5744-5869

4. Grammatopoulos DK, Chrousos GP (2002) Functional characteristics of CRH receptors and potential clinical applications of CRHreceptor antagonists. Trends Endocrinol Metab 13:436-444

5. Roh J, Chang CL, Bhalla A, Klein C, Hsu SY (2004) Intermedin is a calcitonin/calcitonin gene-related peptide family peptide acting through the calcitonin receptor-like receptor/receptor activitymodifying protein receptor complexes. J Biol Chem 279:7264 7274

6. Russell FA, King R, Smillie SJ, Kodji X, Brain SD (2014) Calcitonin gene-related peptide: physiology and pathophysiology. Physiol Rev 94:1099-1142

7. Poyner DR, Sexton PM, Marshall I et al (2002) International Union of Pharmacology. XXXII. The mammalian calcitonin gene-related peptides, adrenomedullin, amylin, and calcitonin receptors. Pharmacol Rev 54:233-246

8. Hay DL, Christopoulos G, Christopoulos A, Poyner DR, Sexton PM (2005) Pharmacological discrimination of calcitonin receptor: receptor activity-modifying protein complexes. Mol Pharmacol 67:1655-1665

9. Sexton PM, Albiston A, Morfis M, Tilakaratne N (2001) Receptor activity modifying proteins. Cell Signal 13:73-83

10. Gingell JJ, Simms J, Barwell J et al (2016) An allosteric role for receptor activity-modifying proteins in defining GPCR pharmacology. Cell Discov 2:16020

11. Wootten D, Lindmark H, Kadmiel M et al (2013) Receptor activity modifying proteins (RAMPs) interact with the VPAC2 receptor and CRF1 receptors and modulate their function. Br J Pharmacol 168:822-834

12. Christopoulos A, Christopoulos G, Morfis M et al (2003) Novel receptor partners and function of receptor activity-modifying proteins. J Biol Chem 278:3293-3297

13. Degn KB, Juhl CB, Sturis J et al (2004) One week's treatment with the long-acting glucagon-like peptide 1 derivative liraglutide (NN2211) markedly improves 24-h glycemia and alpha- and beta-cell function and reduces endogenous glucose release in patients with type 2 diabetes. Diabetes 53:1187-1194

14. Agerso H, Jensen LB, Elbrond B, Rolan P, Zdravkovic M (2002) The pharmacokinetics, pharmacodynamics, safety and tolerability of NN2211, a new long-acting GLP-1 derivative, in healthy men. Diabetologia 45:195-202

15. Berkovic MC, Bilic-Curcic I, Herman Mahecic D, Gradiser M, Grgurevic M, Bozek T (2017) Long-term effectiveness of Liraglutide in association with Patients' baseline characteristics in real-life setting in Croatia: an observational, retrospective, multicenter study. Diabetes Ther 8:1297-1308

16. Hiramatsu T, Ozeki A, Ishikawa H, Furuta S (2017) Long term effects of Liraglutide in Japanese patients with type 2 diabetes among the subgroups with different renal functions: results of 2year prospective study. Drug Res(Stuttg) 67:640-646

17. Marso SP, Daniels GH, Brown-Frandsen K et al (2016) Liraglutide and cardiovascular outcomes in type 2 diabetes. $\mathrm{N}$ Engl J Med 375:311-322

18. JFE M, Orsted DD, Brown-Frandsen K et al LEADER Steering Committee Investigators 2017 Liraglutide and Renal Outcomes in Type 2 Diabetes. N Engl J Med 377:839-848

19. Riddle M, Frias J, Zhang B et al (2007) Pramlintide improved glycemic control and reduced weight in patients with type 2 diabetes using basal insulin. Diabetes Care 30:2794-2799

20. Riddle M, Pencek R, Charenkavanich S, Lutz K, Wilhelm K, Porter L (2009) Randomized comparison of pramlintide or mealtime insulin added to basal insulin treatment for patients with type 2 diabetes. Diabetes Care 32:1577-1582

21. Monnier L (2007) Is pramlintide a safe and effective adjunct therapy for patients with type 1 diabetes? Nat Clin Pract Endocrinol Metab 3:332-333

22. Grunfeld C, Dritselis A, Kirkpatrick P (2011) Tesamorelin. Nat Rev Drug Discov 10:95-96

23. Miller PD, Bilezikian JP, Deal C, Harris ST, Ci RP (2004) Clinical use of teriparatide in the real world: initial insights. Endocr Pract 10:139-148

24. Orwoll ES, Shapiro J, Veith S et al (2014) Evaluation of teriparatide treatment in adults with osteogenesis imperfecta. J Clin Invest 124:491-498

25. Kraenzlin ME, Meier C (2011) Parathyroid hormone analogues in the treatment of osteoporosis. Nat Rev Endocrinol 7:647-656

26. Shirley M (2017) Abaloparatide: First Global Approval. Drugs 77: 1363-1368

27. Leder BZ, O'Dea LS, Zanchetta JR et al (2015) Effects of abaloparatide, a human parathyroid hormone-related peptide ana$\log$, on bone mineral density in postmenopausal women with osteoporosis. J Clin Endocrinol Metab 100:697-706

28. Yoh K, Uzawa T, Orito T, Tanaka K (2012) Improvement of quality of life (QOL) in osteoporotic patients by Elcatonin treatment: a trial 
taking the Participants' preference into account. Jpn Clin Med 3:914

29. Brunton L, Parker K, Blumenthal D, Buxton I. Goodman and Gilman's. Manual of Pharmacology and Therapeutics. The McGraw-Hill Companies, Inc.

30. Jeppesen PB (2006) Glucagon-like peptide-2: update of the recent clinical trials. Gastroenterology 130(Suppl 1):27-131

31. Jeppesen PB, Sanguinetti EL, Buchman A et al (2005) Teduglutide (ALX-0600), a dipeptidyl peptidase IV resistant glucagon-like peptide 2 analogue, improves intestinal function in short bowel syndrome patients. Gut 54:1224-1231

32. Marier JF, Beliveau M, Mouksassi MS et al (2008) Pharmacokinetics, safety, and tolerability of teduglutide, a glucagon-like peptide-2 (GLP-2) analog, following multiple ascending subcutaneous administrations in healthy subjects. J Clin Pharmacol 48:1289-1299

33. Goadsby PJ, Reuter U, Hallstrom Y et al (2017) A controlled trial of Erenumab for episodic migraine. N Engl J Med 377:2123-2132

34. Schuster NM, Rapoport AM (2017) Calcitonin gene-related peptide-targeted therapies for migraine and cluster headache: a review. Clin Neuropharmacol 40:169-174

35. Zorrilla EP, Koob GF (2010) Progress in corticotropin-releasing factor-1 antagonist development. Drug Discov Today 15:371-383

36. Zorrilla EP, Heilig M, de Wit H, Shaham Y (2013) Behavioral, biological, and chemical perspectives on targeting CRF(1) receptor antagonists to treat alcoholism. Drug Alcohol Depend 128: $175-186$

37. 2004 Corticorelin: ACTH RF, corticoliberin, corticotrophinreleasing hormone, corticotropin-releasing factor, human corticotropin-releasing hormone, ovine corticotrophin-releasing factor, Xerecept. Drugs RD 5: 218-219

38. Recht L, Mechtler LL, Wong ET, O'Connor PC, Rodda BE (2013) Steroid-sparing effect of corticorelin acetate in peritumoral cerebral edema is associated with improvement in steroid-induced myopathy. J Clin Oncol 31:1182-1187

39. Kornreich WD, Galyean R, Hernandez JF et al (1992) Alanine series of ovine corticotropin releasing factor (oCRF): a structureactivity relationship study. J Med Chem 35:1870-1876

40. Nicole P, Lins L, Rouyer-Fessard C et al (2000) Identification of key residues for interaction of vasoactive intestinal peptide with human VPAC1 and VPAC2 receptors and development of a highly selective VPAC1 receptor agonist. Alanine scanning and molecular modeling of the peptide. J Biol Chem 275:24003-24012

41. Igarashi H, Ito T, Hou W et al (2002) Elucidation of vasoactive intestinal peptide pharmacophore for VPAC(1) receptors in human, rat, and Guinea pig. J Pharmacol Exp Ther 301:37-50

42. Bourgault S, Vaudry D, Segalas-Milazzo I et al (2009) Molecular and conformational determinants of pituitary adenylate cyclaseactivating polypeptide (PACAP) for activation of the PAC1 receptor. J Med Chem 52:3308-3316

43. Adelhorst K, Hedegaard BB, Knudsen LB, Kirk O (1994) Structure-activity studies of glucagon-like peptide-1. J Biol Chem 269:6275-6278

44. Dong M, Le A, Te JA, Pinon DI, Bordner AJ, Miller LJ (2011) Importance of each residue within secretin for receptor binding and biological activity. Biochemistry 50:2983-2993

45. Watkins HA, Au M, Bobby R et al (2013) Identification of key residues involved in adrenomedullin binding to the AM1 receptor. Br J Pharmacol 169:143-155

46. Bourgault S, Vaudry D, Guilhaudis L et al (2008) Biological and structural analysis of truncated analogs of PACAP27. J Mol Neurosci 36:260-269

47. Vale W, Spiess J, Rivier C, Rivier J (1981) Characterization of a 41-residue ovine hypothalamic peptide that stimulates secretion of corticotropin and beta-endorphin. Science 213:1394-1397
48. Ohta N, Mochizuki T, Hoshino M, Jun L, Kobayashi H, Yanaihara N (1997) Adrenocorticotropic hormone-releasing activity of urotensin I and its fragments in vitro. J Pept Res 50:178-183

49. Rivier J, Rivier C, Vale W (1984) Synthetic competitive antagonists of corticotropin-releasing factor: effect on ACTH secretion in the rat. Science 224:889-891

50. Turner JT, Jones SB, Bylund DB (1986) A fragment of vasoactive intestinal peptide, VIP(10-28), is an antagonist of VIP in the colon carcinoma cell line, HT29. Peptides 7:849-854

51. Goke R, Fehmann HC, Linn T et al (1993) Exendin-4 is a high potency agonist and truncated exendin-(9-39)-amide an antagonist at the glucagon-like peptide 1-(7-36)-amide receptor of insulinsecreting beta-cells. J Biol Chem 268:19650-19655

52. Pozvek G, Hilton JM, Quiza M, Houssami S, Sexton PM (1997) Structure/function relationships of calcitonin analogues as agonists, antagonists, or inverse agonists in a constitutively activated receptor cell system. Mol Pharmacol 51:658-665

53. Montrose-Rafizadeh C, Yang H, Rodgers BD, Beday A, Pritchette LA, Eng J (1997) High potency antagonists of the pancreatic glucagon-like peptide-1 receptor. J Biol Chem 272:21201-21206

54. Runge S, Thogersen H, Madsen K, Lau J, Rudolph R (2008) Crystal structure of the ligand-bound glucagon-like peptide-1 receptor extracellular domain. J Biol Chem 283:11340-11347

55. Underwood CR, Garibay P, Knudsen LB et al (2010) Crystal structure of glucagon-like peptide- 1 in complex with the extracellular domain of the glucagon-like peptide-1 receptor. J Biol Chem 285:723-730

56. Parthier C, Kleinschmidt M, Neumann P et al (2007) Crystal structure of the incretin-bound extracellular domain of a $\mathrm{G}$ protein-coupled receptor. Proc Natl Acad Sci U S A 104:1394213947

57. Sun C, Song D, Davis-Taber RA et al (2007) Solution structure and mutational analysis of pituitary adenylate cyclase-activating polypeptide binding to the extracellular domain of PAC1-RS. Proc Natl Acad Sci U S A 104:7875-7880

58. Pioszak AA, Xu HE (2008) Molecular recognition of parathyroid hormone by its $\mathrm{G}$ protein-coupled receptor. Proc Natl Acad Sci U S A 105:5034-5039

59. Grace CR, Perrin MH, Gulyas J et al (2007) Structure of the Nterminal domain of a type B1 G protein-coupled receptor in complex with a peptide ligand. Proc Natl Acad Sci U S A 104:48584863

60. Inooka H, Ohtaki $\mathrm{T}$, Kitahara $\mathrm{O}$ et al (2001) Conformation of a peptide ligand bound to its G-protein coupled receptor. Nat Struct Biol 8:161-165

61. Pallai PV, Mabilia M, Goodman M, Vale W, Rivier J (1983) Structural homology of corticotropin-releasing factor, sauvagine, and urotensin I: circular dichroism and prediction studies. Proc Natl Acad Sci U S A 80:6770-6774

62. Dathe M, Fabian H, Gast K et al (1996) Conformational differences of ovine and human corticotropin releasing hormone. A CD, IR, NMR and dynamic light scattering study. Int J Pept Protein Res 47:383-393

63. Lau SH, Rivier J, Vale W, Kaiser ET, Kezdy FJ (1983) Surface properties of an amphiphilic peptide hormone and of its analog: corticotropin-releasing factor and sauvagine. Proc Natl Acad Sci U S A 80:7070-7074

64. Neidigh JW, Fesinmeyer RM, Prickett KS, Andersen NH (2001) Exendin-4 and glucagon-like-peptide-1: NMR structural comparisons in the solution and micelle-associated states. Biochemistry 40:13188-13200

65. Chang X, Keller D, Bjørn S, Led JJ (2001) Structure and folding of glucagon-like peptide-1-(7-36)-amide in aqueous trifluoroethanol studied by NMR spectroscopy. Magn Reson Chem 39:477-483 
66. Fry DC, Madison VS, Bolin DR, Greeley DN, Toome V, Wegrzynski BB (1989) Solution structure of an analogue of vasoactive intestinal peptide as determined by two-dimensional NMR and circular dichroism spectroscopies and constrained molecular dynamics. Biochemistry 28:2399-2409

67. Gronenborn AM, Bovermann G, Clore GM (1987) A 1H-NMR study of the solution conformation of secretin. Resonance assignment and secondary structure. FEBS Lett 215:88-94

68. Braun W, Wider G, Lee KH, Wuthrich K (1983) Conformation of glucagon in a lipid-water interphase by $1 \mathrm{H}$ nuclear magnetic resonance. J Mol Biol 169:921-948

69. Wray V, Kakoschke C, Nokihara K, Naruse S (1993) Solution structure of pituitary adenylate cyclase activating polypeptide by nuclear magnetic resonance spectroscopy. Biochemistry 32:58325841

70. Sasaki K, Dockerill S, Adamiak DA, Tickle IJ, Blundell T (1975) $\mathrm{X}$-ray analysis of glucagon and its relationship to receptor binding. Nature 257:751-757

71. Motta A, Andreotti G, Amodeo P, Strazzullo G, Castiglione Morelli MA (1998) Solution structure of human calcitonin in membrane-mimetic environment: the role of the amphipathic helix. Proteins 32:314-323

72. Thornton K, Gorenstein DG (1994) Structure of glucagon-like peptide (7-36) amide in a dodecylphosphocholine micelle as determined by 2D NMR. Biochemistry 33:3532-3539

73. O'Neil KT, DeGrado WF (1990) A thermodynamic scale for the helix-forming tendencies of the commonly occurring amino acids. Science 250:646-651

74. Beyermann M, Rothemund S, Heinrich $\mathrm{N}$ et al (2000) A role for a helical connector between two receptor binding sites of a longchain peptide hormone. J Biol Chem 275:5702-5709

75. Stroop SD, Kuestner RE, Serwold TF, Chen L, Moore EE (1995) Chimeric human calcitonin and glucagon receptors reveal two dissociable calcitonin interaction sites. Biochemistry 34:1050 1057

76. Lopez de Maturana R, Willshaw A, Kuntzsch A, Rudolph R, Donnelly D (2003) The isolated N-terminal domain of the glucagon-like peptide-1 (GLP-1) receptor binds exendin peptides with much higher affinity than GLP-1. J Biol Chem 278:1019510200

77. Pioszak AA, Parker NR, Suino-Powell K, Xu HE (2008) Molecular recognition of corticotropin-releasing factor by its Gprotein-coupled receptor CRFR1. J Biol Chem 283:32900-32912

78. Pal K, Swaminathan K, Xu HE, Pioszak AA (2010) Structural basis for hormone recognition by the human CRFR2 \{alpha\} G protein-coupled receptor. J Biol Chem 285:40351-40361

79. Harikumar KG, Lam PC, Dong M, Sexton PM, Abagyan R, Miller LJ (2007) Fluorescence resonance energy transfer analysis of secretin docking to its receptor: mapping distances between residues distributed throughout the ligand pharmacophore and distinct receptor residues. J Biol Chem 282:32834-32843

80. Perrin MH, Sutton S, Bain DL, Berggren WT, Vale WW (1998) The first extracellular domain of corticotropin releasing factor-R1 contains major binding determinants for urocortin and astressin. Endocrinology 139:566-570

81. Klose J, Fechner K, Beyermann M et al (2005) Impact of Nterminal domains for corticotropin-releasing factor (CRF) receptor-ligand interactions. Biochemistry 44:1614-1623

82. Mesleh MF, Shirley WA, Heise CE, Ling N, Maki RA, Laura RP (2007) NMR structural characterization of a minimal peptide antagonist bound to the extracellular domain of the corticotropinreleasing factor1 receptor. J Biol Chem 282:6338-6346

83. Runge S, Wulff BS, Madsen K, Brauner-Osborne H, Knudsen LB (2003) Different domains of the glucagon and glucagon-like peptide- 1 receptors provide the critical determinants of ligand selectivity. Br J Pharmacol 138:787-794
84. Dong M, Pinon DI, Cox RF, Miller LJ (2004) Importance of the amino terminus in secretin family $\mathrm{G}$ protein-coupled receptors. Intrinsic photoaffinity labeling establishes initial docking constraints for the calcitonin receptor. J Biol Chem 279:1167-1175

85. Gkountelias K, Tselios T, Venihaki M et al (2009) Alanine scanning mutagenesis of the second extracellular loop of type 1 corticotropin-releasing factor receptor revealed residues critical for peptide binding. Mol Pharmacol 75:793-800

86. Assil-Kishawi I, Abou-Samra AB (2002) Sauvagine cross-links to the second extracellular loop of the corticotropin-releasing factor type 1 receptor. J Biol Chem 277:32558-32561

87. Kraetke O, Holeran B, Berger H, Escher E, Bienert M, Beyermann $M$ (2005) Photoaffinity cross-linking of the corticotropinreleasing factor receptor type 1 with photoreactive urocortin analogues. Biochemistry 44:15569-15577

88. Assil-Kishawi I, Samra TA, Mierke DF, Abou-Samra AB (2008) Residue 17 of sauvagine cross-links to the first transmembrane domain of corticotropin-releasing factor receptor 1 (CRFR1). J Biol Chem 283:35644-35651

89. Coin I, Katritch V, Sun T et al (2013) Genetically encoded chemical probes in cells reveal the binding path of urocortin-I to CRF class B GPCR. Cell 155:1258-1269

90. Bisello A, Adams AE, Mierke DF et al (1998) Parathyroid hormone-receptor interactions identified directly by photocrosslinking and molecular modeling studies. J Biol Chem 273: 22498-22505

91. Dong M, Li Z, Pinon DI, Lybrand TP, Miller LJ (2004) Spatial approximation between the amino terminus of a peptide agonist and the top of the sixth transmembrane segment of the secretin receptor. J Biol Chem 279:2894-2903

92. Dong M, Pinon DI, Cox RF, Miller LJ (2004) Molecular approximation between a residue in the amino-terminal region of calcitonin and the third extracellular loop of the class B G proteincoupled calcitonin receptor. J Biol Chem 279:31177-31182

93. Dong M, Xu X, Ball AM, Makhoul JA, Lam PC, Pinon DI, Orry A, Sexton PM, Abagyan R, Miller LJ (2012) Mapping spatial approximations between the amino terminus of secretin and each of the extracellular loops of its receptor using cysteine trapping. FASEB J 26:5092-5105

94. Runge S, Gram C, Brauner-Osborne H, Madsen K, Knudsen LB, Wulff BS (2003) Three distinct epitopes on the extracellular face of the glucagon receptor determine specificity for the glucagon amino terminus. J Biol Chem 278:28005-28010

95. Al-Sabah S, Donnelly D (2003) The positive charge at Lys-288 of the glucagon-like peptide-1 (GLP-1) receptor is important for binding the N-terminus of peptide agonists. FEBS Lett 553:342346

96. Di Paolo E, De Neef P, Moguilevsky N et al (1998) Contribution of the second transmembrane helix of the secretin receptor to the positioning of secretin. FEBS Lett 424:207-210

97. Bergwitz C, Gardella TJ, Flannery MR et al (1996) Full activation of chimeric receptors by hybrids between parathyroid hormone and calcitonin. Evidence for a common pattern of ligandreceptor interaction. J Biol Chem 271:26469-26472

98. Hoare SR, Fleck BA, Gross RS, Crowe PD, Williams JP, Grigoriadis DE (2008) Allosteric ligands for the corticotropin releasing factor type 1 receptor modulate conformational states involved in receptor activation. Mol Pharmacol 73:1371-1380

99. Hoare SR, Sullivan SK, Schwarz DA et al (2004) Ligand affinity for amino-terminal and juxtamembrane domains of the corticotropin releasing factor type I receptor: regulation by G-protein and nonpeptide antagonists. Biochemistry 43:3996-4011

100. Hoare SR, Gardella TJ, Usdin TB (2001) Evaluating the signal transduction mechanism of the parathyroid hormone 1 receptor. Effect of receptor-G-protein interaction on the ligand binding 
mechanism and receptor conformation. J Biol Chem 276:77417753

101. Nielsen SM, Nielsen LZ, Hjorth SA, Perrin MH, Vale WW (2000) Constitutive activation of tethered-peptide/corticotropin-releasing factor receptor chimeras. Proc Natl Acad Sci U S A 97:1027710281

102. Spyridaki K, Matsoukas MT, Cordomi A et al (2014) Structuralfunctional analysis of the third transmembrane domain of the corticotropin-releasing factor type 1 receptor: role in activation and allosteric antagonism. J Biol Chem 289:18966-18977

103. Castro M, Nikolaev VO, Palm D, Lohse MJ, Vilardaga JP (2005) Turn-on switch in parathyroid hormone receptor by a two-step parathyroid hormone binding mechanism. Proc Natl Acad Sci U S A 102:16084-16089

104. Koth CM, Murray JM, Mukund S et al (2012) Molecular basis for negative regulation of the glucagon receptor. Proc Natl Acad Sci U S A 109:14393-14398

105. Grace CR, Perrin MH, DiGruccio MR et al (2004) NMR structure and peptide hormone binding site of the first extracellular domain of a type B1 G protein-coupled receptor. Proc Natl Acad Sci U S A 101:12836-12841

106. Grace CR, Perrin MH, Gulyas J et al (2010) NMR structure of the first extracellular domain of corticotropin-releasing factor receptor 1 (ECD1-CRF-R1) complexed with a high affinity agonist. J Biol Chem 285:38580-38589

107. Pioszak AA, Parker NR, Gardella TJ, Xu HE (2009) Structural basis for parathyroid hormone-related protein binding to the parathyroid hormone receptor and design of conformation-selective peptides. J Biol Chem 284:28382-28391

108. Perrin MH, Grace CR, Digruccio MR et al (2007) Distinct structural and functional roles of conserved residues in the first extracellular domain of receptors for corticotropin releasing factor and related G-protein coupled receptors. J Biol Chem 282:37529_ 37536

109. ter Haar E, Koth CM, Abdul-Manan N et al (2010) Crystal structure of the ectodomain complex of the CGRP receptor, a class-B GPCR, reveals the site of drug antagonism. Structure 18:10831109

110. Norman DG, Barlow PN, Baron M, Day AJ, Sim RB, Campbell ID (1991) Three-dimensional structure of a complement control protein module in solution. J Mol Biol 219:717-725

111. Perrin MH, Grace CR, Riek R, Vale WW (2006) The threedimensional structure of the N-terminal domain of corticotropinreleasing factor receptors: sushi domains and the B1 family of $\mathrm{G}$ protein-coupled receptors. Ann N Y Acad Sci 1070:105-119

112. Wilmen A, Goke B, Goke R (1996) The isolated N-terminal extracellular domain of the glucagon-like peptide-1 (GLP)-1 receptor has intrinsic binding activity. FEBS Lett 398:43-47

113. Gaudin P, Couvineau A, Maoret JJ, Rouyer-Fessard C, Laburthe M (1995) Mutational analysis of cysteine residues within the extracellular domains of the human vasoactive intestinal peptide (VIP) 1 receptor identifies seven mutants that are defective in VIP binding. Biochem Biophys Res Commun 211:901-908

114. Qi LJ, Leung AT, Xiong Y, Marx KA, Abou-Samra AB (1997) Extracellular cysteines of the corticotropin-releasing factor receptor are critical for ligand interaction. Biochemistry 36:1244212448

115. Lin SC, Lin CR, Gukovsky I, Lusis AJ, Sawchenko PE, Rosenfeld MG (1993) Molecular basis of the little mouse phenotype and implications for cell type-specific growth. Nature 364:208-213

116. Parameswaran N, Spielman WS (2006) RAMPs: the past, present and future. Trends Biochem Sci 31:631-638

117. Hay DL, Pioszak AA (2016) Receptor activity-modifying proteins (RAMPs): new insights and roles. Annu Rev Pharmacol Toxicol $56: 469-487$
118. Weston C, Winfield I, Harris M et al (2016) Receptor activitymodifying protein-directed $\mathrm{G}$ protein signaling specificity for the calcitonin gene-related peptide family of receptors. J Biol Chem 291:21925-21944

119. Archbold JK, Flanagan JU, Watkins HA, Gingell JJ, Hay DL (2011) Structural insights into RAMP modification of secretin family G protein-coupled receptors: implications for drug development. Trends Pharmacol Sci 32:591-600

120. de Graaf C, Song G, Cao C et al (2017) Extending the structural view of class B GPCRs. Trends Biochem Sci 42:946-960

121. Siu FY, He M, de Graaf C et al (2013) Structure of the human glucagon class B G-protein-coupled receptor. Nature 499:444449

122. Jazayeri A, Dore AS, Lamb D et al (2016) Extra-helical binding site of a glucagon receptor antagonist. Nature 533:274-277

123. Hollenstein K, Kean J, Bortolato A et al (2013) Structure of class B GPCR corticotropin-releasing factor receptor 1. Nature 499: 438-443

124. Song G, Yang D, Wang Y et al (2017) Human GLP-1 receptor transmembrane domain structure in complex with allosteric modulators. Nature 546:312-315

125. Zhang Y, Sun B, Feng D et al (2017) Cryo-EM structure of the activated GLP-1 receptor in complex with a G protein. Nature 546: 248-253

126. Zhang H, Qiao A, Yang D et al (2017) Structure of the full-length glucagon class B G-protein-coupled receptor. Nature 546:259 264

127. Liang YL, Khoshouei M, Radjainia M et al (2017) Phase-plate cryo-EM structure of a class B GPCR-G-protein complex. Nature 546:118-123

128. Bortolato A, Dore AS, Hollenstein K, Tehan BG, Mason JS, Marshall FH (2014) Structure of class B GPCRs: new horizons for drug discovery. Br J Pharmacol 171:3132-3145

129. Ballesteros J, Weinstein H (1995) Integrated methods for the construction of three-dimensional models of structure-function relations in $\mathrm{G}$ protein-coupled receptors. Methods in. Neurosciences 25:366-428

130. Wootten D, Simms J, Miller LJ, Christopoulos A, Sexton PM (2013) Polar transmembrane interactions drive formation of ligand-specific and signal pathway-biased family B G proteincoupled receptor conformations. Proc Natl Acad Sci U S A 110: 5211-5216

131. Rasmussen SG, DeVree BT, Zou Y et al (2011) Crystal structure of the beta2 adrenergic receptor-Gs protein complex. Nature 477: 549-555

132. Rashid AJ, O'Dowd BF, George SR (2004) Minireview: diversity and complexity of signaling through peptidergic $\mathrm{G}$ proteincoupled receptors. Endocrinology 145:2645-2652

133. Hillhouse EW, Grammatopoulos DK (2006) The molecular mechanisms underlying the regulation of the biological activity of corticotropin-releasing hormone receptors: implications for physiology and pathophysiology. Endocr Rev 27:260-286

134. Culhane KJ, Liu Y, Cai Y, Yan EC (2015) Transmembrane signal transduction by peptide hormones via family B G protein-coupled receptors. Front Pharmacol 6:264

135. Punn A, Chen J, Delidaki M et al (2012) Mapping structural determinants within third intracellular loop that direct signaling specificity of type 1 corticotropin-releasing hormone receptor. J Biol Chem 287:8974-8985

136. Conner AC, Simms J, Conner MT, Wootten DL, Wheatley M, Poyner DR (2006) Diverse functional motifs within the three intracellular loops of the CGRP1 receptor. Biochemistry 45:1297612985

137. Huang Z, Chen Y, Pratt S et al (1996) The N-terminal region of the third intracellular loop of the parathyroid hormone (PTH)/PTHrelated peptide receptor is critical for coupling to cAMP and 
inositol phosphate/Ca2+ signal transduction pathways. J Biol Chem 271:33382-33389

138. Hallbrink M, Holmqvist T, Olsson M, Ostenson CG, Efendic S, Langel U (2001) Different domains in the third intracellular loop of the GLP-1 receptor are responsible for Galpha(s) and Galpha(i)/ Galpha(o) activation. Biochim Biophys Acta 1546:79-86

139. Chan KY, Pang RT, Chow BK (2001) Functional segregation of the highly conserved basic motifs within the third endoloop of the human secretin receptor. Endocrinology 142:3926-3934

140. Mathi SK, Chan Y, Li X, Wheeler MB (1997) Scanning of the glucagon-like peptide-1 receptor localizes $G$ protein-activating determinants primarily to the $\mathrm{N}$ terminus of the third intracellular loop. Mol Endocrinol 11:424-432

141. Couvineau A, Lacapere JJ, Tan YV, Rouyer-Fessard C, Nicole P, Laburthe M (2003) Identification of cytoplasmic domains of hVPAC1 receptor required for activation of adenylyl cyclase. Crucial role of two charged amino acids strictly conserved in class II G protein-coupled receptors. J Biol Chem 278:24759-24766

142. Garcia GL, Dong M, Miller LJ (2012) Differential determinants for coupling of distinct $\mathrm{G}$ proteins with the class B secretin receptor. Am J Physiol Cell Physiol 302:C1202-C1212

143. Bavec A, Hallbrink M, Langel U, Zorko M (2003) Different role of intracellular loops of glucagon-like peptide-1 receptor in Gprotein coupling. Regul Pept 111:137-144

144. Cypess AM, Unson CG, Wu CR, Sakmar TP (1999) Two cytoplasmic loops of the glucagon receptor are required to elevate cAMP or intracellular calcium. J Biol Chem 274:19455-19464

145. Takhar S, Gyomorey S, Su RC, Mathi SK, Li X, Wheeler MB (1996) The third cytoplasmic domain of the GLP-1[7-36 amide] receptor is required for coupling to the adenylyl cyclase system. Endocrinology 137:2175-2178

146. Iida-Klein A, Guo J, Takemura M et al (1997) Mutations in the second cytoplasmic loop of the rat parathyroid hormone (PTH)/ PTH-related protein receptor result in selective loss of PTHstimulated phospholipase C activity. J Biol Chem 272:6882-6889

147. Ferrandon S, Feinstein TN, Castro M et al (2009) Sustained cyclic AMP production by parathyroid hormone receptor endocytosis. Nat Chem Biol 5:734-742

148. Rasmussen SG, Choi H-J, Fung JJ et al (2011) Structure of a nanobody-stabilized active state of the [bgr] 2 adrenoceptor. Nature 469:175-180

149. Chen YL, Obach RS, Braselton J et al (2008) 2-aryloxy-4alkylaminopyridines: discovery of novel corticotropin-releasing factor 1 antagonists. J Med Chem 51:1385-1392

150. Hoare SR, Brown BT, Santos MA, Malany S, Betz SF, Grigoriadis DE (2006) Single amino acid residue determinants of non-peptide antagonist binding to the corticotropin-releasing factor1 (CRF1) receptor. Biochem Pharmacol 72:244-255

151. Liaw CW, Grigoriadis DE, Lorang MT, De Souza EB, Maki RA (1997) Localization of agonist- and antagonist-binding domains of human corticotropin-releasing factor receptors. Mol Endocrinol 11:2048-2053

152. Sun X, Cheng J, Wang X, Tang Y, Agren H, Tu Y (2015) Residues remote from the binding pocket control the antagonist selectivity towards the corticotropin-releasing factor receptor-1. Sci Rep 5: 8066 